\title{
On the Occurrence of Galemys kormosi (Schreuder, 1940) (Insectivora: Desmaninae) in the British Lower Pleistocene
}

\author{
D. L. HARRISON P. J. J. BATES \& J. D. CLAYDEN
}

\begin{abstract}
Harrison D.L., Bates P.J.J. \& Clayden, J.D., 1988: On the occurrence of Galemys kormosi (Schreuder, 1940) (Insectivora: Desmaninae) in the British Lower Pleistocene. Acta theriol., 33, 26: 369-378. [With 1 Table \& 7 Figs]

The presence of Galemys kormosi (Schreuder, 1940) is recorded for the first time from the British Isles. It is reported from the Pre-Pastonian/Pastonian Crags of the Lower Pleistocene of Sidestrand and East Runton and at West Runton, Norfolk. This corresponds to its occurrence in the Late Villanyian of the Continent.

[D.L.H. \& P.J.J.B.: Harrison Zoological Museum, Bowerwood House, St Botolphs Road, Sevenoaks, Kent, England, TN13 3AQ. J.D.C.: Sunnyholme, Lower Green, East Runton, near Cromer, Norfolk, England]
\end{abstract}

\section{INTRODUCTION}

Remains of fossil Water moles referred to the living subfamily Desmaninae are well known in British sites of early Middle Pleistocene (broadly Cromerian) age, such as West Runton (Stuart, 1982) and Westbury-Sub-Mendip (Bishop, 1982). Remains of these animals are however, extremely rare and little-known in the British Lower Pleistocene. Mayhew (1985) recorded Desmana from Weybourne and Bulcamp, while Stuart (1982) first noted the presence of a rare and undetermined species from the Pastonian Crag of West Runton. This specimen, a single $\mathrm{p}^{4}$ was considered referable to a then undetermined species found in the Tiglian stage Tc5 of Tegelen, the Netherlands (Freudenthal et al., 1976). A definitive study of fossil Desmaninae has now been made by Rumke (1985). Of special relevance to this studyis the included identification of the abundant remains of a large Desman, Desmana thermalis Kormos, 1930 and a smaller species $\mathrm{Ga}$ lemys kormosi (Schreuder, 1940), from the Tegelen deposits. The latter is considered to be the ancestor of the extant Galemys pyrenaicus (Geoffroy, 1811), a rare relict species confined to the mountains of the Pyrenees and the Iberian Peninsula.

During the past two years the Harrison Zoological Museum, in collaboration with John Clayden of East Runton and Martin Warren of 
the Cromer Museum, has undertaken an intensive investigation of the Lower Pleistocene Weybourne Crag deposits of Sidestrand, Norfolk. A full report on the small mammal fauna of these deposits and their geology is in preparation. It will suffice to state here that all the deposits sampled are considered to be broadly Pre-Pastonian/Pastonian in the sense of the palynological research of West (1980).

It became clear at an early stage of our investigation that very rare remains of two species of Desman were present in the Sidestrand deposits, a large species of Desmana, considered provisionally to represent $D$. thermalis and a small species now considered to represent Galemys kormosi. The latter has also been recovered by one of us (J.D.C.) from the Lower Pleistocene foreshore crags at East Runton. These deposits are believed to be of similar age to Sidestrand (Mayhew \& Stuart, 1986).

Since Galemys kormosi is a new species for Britain, its occurrence in these Lower Pleistocene deposits was considered worthy of a special short report, in advance of the full account of the Sidestrand fauna which will necessarily be some time in preparation.

Teeth

2. MATERIAL OF GALEMYS KORMOSI

Left $\mathrm{m}_{3}$

HZM 5.17969 Sidestrand, Weybourne Crag (Site S-S3)

Right $\mathrm{p}^{4}$

WRC 614 West Runton, Pre-Pastonian/Pastonian Crag

Posteranial

Calcaneum

HZM 1.16885 Sidestrand, Weybourne Crag (Site S-S1) (intact)

HZM 4.17981 Sidestrand, Weybourne Crag (Site S-S3) (heavily rolled) JCER 5 East Runton, Foreshore Crag (intact, perfectly preserved)

\section{Tibia}

HZM 2.17835 Sidestrand, Beach Clay conglomerates (Site S-S2) (intact distal tibia)

JCER 4 East Runton, Beach Shelly Crag (intact distal tibia)

\section{Phalanges}

HZM 3.17917 Sidestrand, Sands overlying Weybourne Crag (Site S-S4) HZM 6.17970 Sidestrand, Sands overlying Weybourne Crag (Site S-S4) JCER 7 East Runton, Beach Shelly Crag 
A
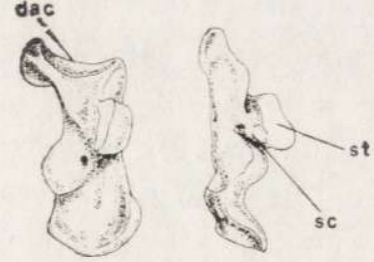

B
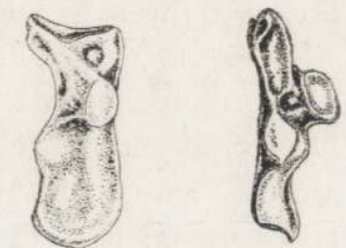

C
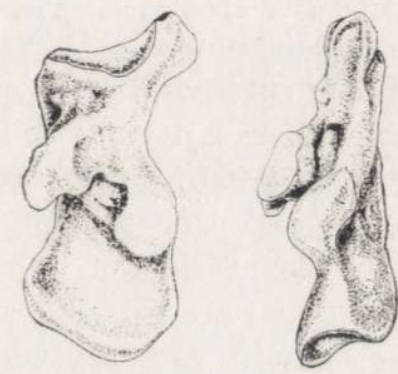

D
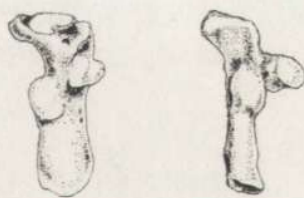

Fig. 1. Lateral (left) and dorsal (right) views of the calcanea of four species of Talpidae A: Galemys pyrenaicus. BM 1960.10.11.9 1-1. $5 \mathrm{~km}$ from Alas, Ariege, France (Recent); B: Galemys kormosi. HZM 1.6885 Sidestrand, Norfolk, Weybourne Crag (Pre-Pastonian); C: Desmana moschata. HZM 43.16797 West Runton, near Cromer, Norfolk, Upper Freshwater Bed (Cromerian); D: Talpa europaea. HZM 55.15313 Seal, near Sevenoaks, Kent (Recent); Scale=3 mm. Stereomicroscope drawings by D. L. Harrison.

N. B. HZM Harrison Zoological Museum, JCER: John Clayden Collection, WRC: A. J. Stuart Collection, Cambridge University

\section{DISCUSSION}

Although almost all the specimens referred are postcranial, it is noteworthy that the osteology of Desmans is highly characteristic, so that most skeletal elements can be positively identified (Stuart 1982). 
In the material listed above the calcanea and distal tibiae proved particularly diagnostic on account of their size and anatomical features.

Desmans are highly adapted for aquatic life. Ognev (1982) described in detail the distinctive life-style of D. moschata, noting that "on land it is clumsy as it roams and waddles on its out-turned paws." As a result of the rotation of the foot it is markedly compressed laterally, the digits completely displaced so as to overlap one another and the lateral sides of the metatarsals face towards the sole and not the lower sides.

This rotation of the foot is no doubt associated with the distinctive morphology of the calcaneum in Desmans. In Fig. 1, the perfectly preserved calcaneum of Desmana moschata from the Cromerian Freshwater Bed at West Runton is compared with that of Recent Galemys pyrenaicus, Recent Talpa europaea and the calcaneum from Sidestrand (HZM 1.16885) here referred to Galemys kormosi. The most striking feature of the Desman calcaneum is the vertically orientated distal cuboid articulation in contrast with the more transverse articulation in Talpa europaea, which has a normal (plantigrade) hind foot. It will be seen that in all other anatomical features, such as the deep sulcus calcanei and rather elongated sustentaculum tali, the Sidestrand calcaneum agrees with that of Galemys pyrenaicus and D. moschata. Such differences as are apparent may be attributed to the rolled and polished state of the heavily mineralised Sidestrand specimen. The
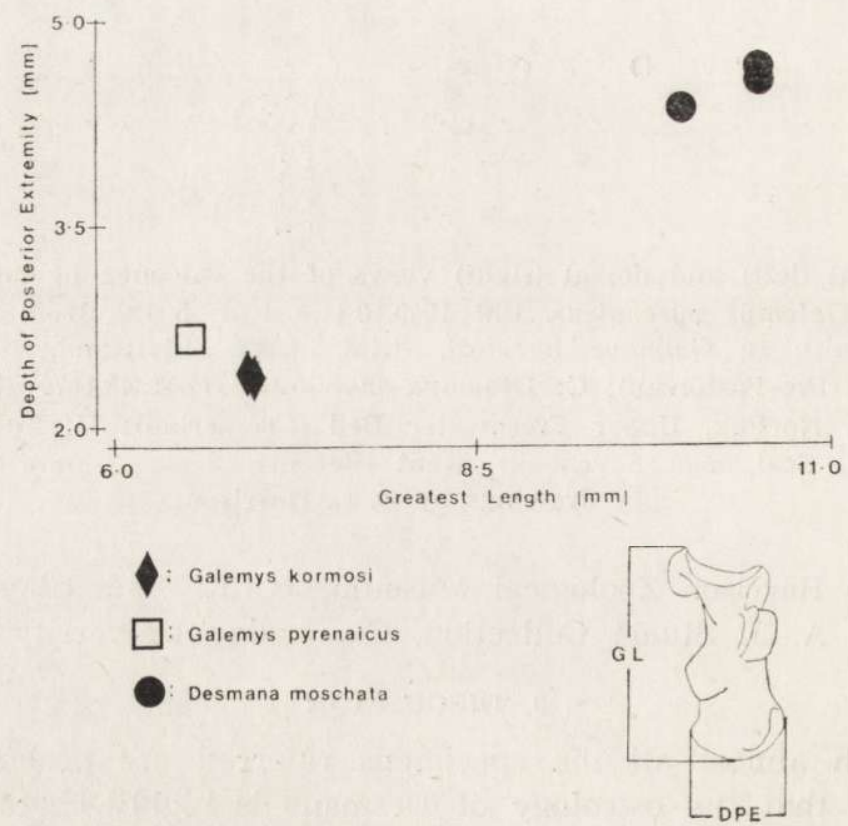

Fig. 2. Size comparison of the calcanea of three species of desman. 
size of this and other intact, referred calcanea is slightly larger than that of the recent G. pyrenaicus and distinctively smaller than D. moschata. This is completely in accord with Rumke's (1985) diagnosis of the species. It is noteworthy however, that even allowing for erosion the proximal extremity in G. kormosi is somewhat narrower (Fig. 2).

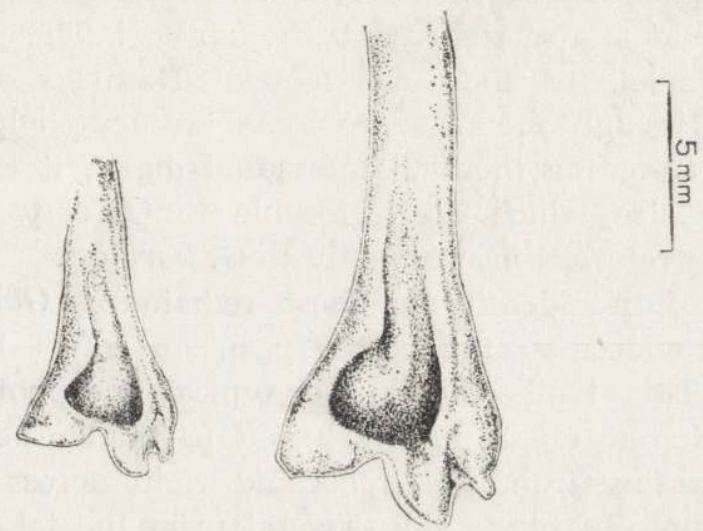

Fig. 3. Distal tibia of two species of desman. Left: Galemys kormosi JCER 4. East Runton, Norfolk (Beach Clay conglomerates, Pre-Pastonian/Pastonian) Right: Desmana moschata HZM 2.14456. West Runton, Norfolk (Cromerian Freshwater Bed). Scale $=5 \mathrm{~mm}$. Stereomicroscope drawings by P. J. J. Bates.

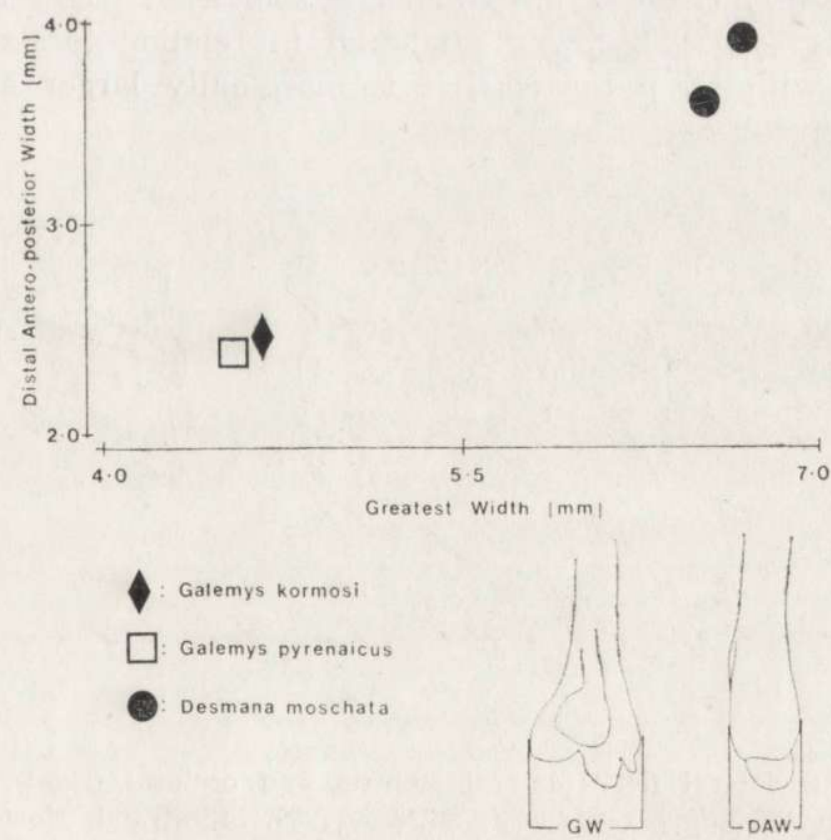

Fig. 4. Size comparison of the tibia of three species of desman. 
The distal tibia of Desmans is also highly distinctive (Fig. 3) and the perfectly preserved specimen from East Runton (JCER 4) shows exactly the same size relationship to that of Cromerian D. moschata from West Runton and to G. pyrenaicus as do the calcanea (Fig. 4). An incomplete distal tibia from Sidestrand (HZM 2.17835) is apparently identical in size and is also referred to G. kormosi. The proximal phalanges and metatarsals of the hind feet of Desmans are also quite distinctive and although the measurements are less helpful, owing to the difficulty in assigning them to individual digits, it is usually clear by their smaller size which are referable to Galemys. Three intact examples are here referred provisionally to $G$. kormosi.

Confirmation of the identity of these remains as Galemys kormosi was however, provided by the recovery of an intact left $\mathrm{m}_{3}$ crown (HZM 5.17969). This tooth shows the typical morphology described and figured by Rumke (1985, fig $16: 2$ ). Of particular note is the long oblique cristid passing from the hypoconid right across the crown to the metaconid, thus separating the trigonid from the talonid by a deep fissure (Fig. 5). The absence of an entostylid identifies this tooth as a lower third molar rather than a lower first or second molar. The presence of a well developed antero-lateral cingulum terminating anteriorly in a distal parastylid is also characteristic. In comparison with Talpa europaea this lower third molar is somewhat larger and distinctively broader (especially in the talonid) in relation to its length. In comparison with $G$. pyrenaicus, it is marginally larger and identical in morphology.
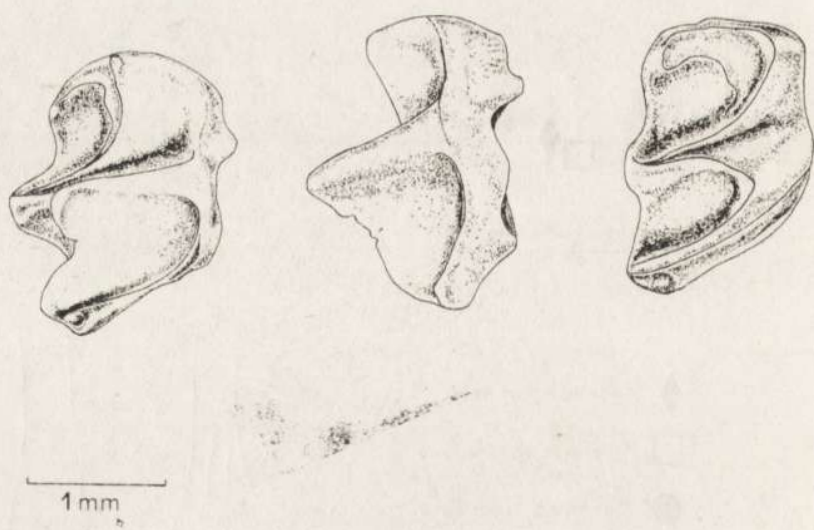

Fig. 5. Oblique lateral (left); lateral (centre) and occlusal (right) views of the left $\mathrm{m}_{3}$ crown of Galemys kormosi, HZM 5.17969, Sidestrand, Norfolk, Weybourne Crag (Site $\mathrm{S}-\mathrm{S} 3$ ). Scale=1 $\mathrm{mm}$. Stereomicroscope drawings by D. L. Harrison. 
The measurements of the tooth following the methods of Rumke (1985, p. 25, Fig. 4) are greatest length (L) $1.83 \mathrm{~mm}$; width of trigonid (W1) $1.41 \mathrm{~mm}$; width of talonid (W2) $1.20 \mathrm{~mm}$. Width of the talonid relative to the greatest length $(\mathrm{W} 2 / \mathrm{L})$ is 0.65 . These measuriments fall well within the range given for the species by Rumke (1985, Table 20a) in particular with material from Tegelen $(\mathrm{L}=1.80-1.91$ $\mathrm{mm} ; \mathrm{W} 2=1.08-1.34 \mathrm{~mm} ; \mathrm{W} 2 / \mathrm{L}=0.60-0.73, \mathrm{n}=7$ ).

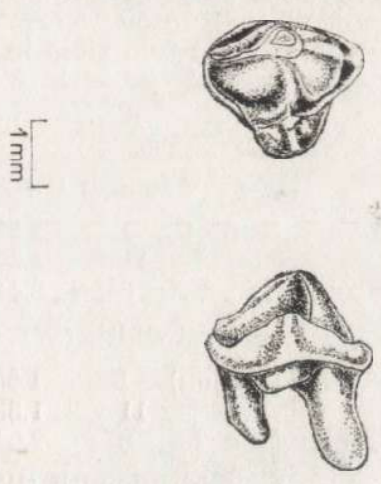

Fig. 6. Occlusal (above) and lingual (below) views of the right $\mathrm{p}^{4}$ of Galemys kormosi, WRC 614, West Runton, Norfolk (Pre-Pastonian/Pastonian Crag). Scale= $=1 \mathrm{~mm}$. Stereomicroscope drawings by D.L. Harrison.

The tooth recovered by Stuart (1982) from West Runton and referred to in the Introduction above has now been re-assessed. The specimen (WRC 614) is a right $\mathrm{p}^{4}$, with intact crown, three-rooted with the tip of the internal root missing. The morphology of the crown (Fig. 6) is exactly as figured by Rumke (1985, Fig. 25.4.) and in size it falls well within the range for this species given by Rumke in Table 20b, p. 177. Its length slightly exceeds the series from Tegelen, but falls below the range of material from the lower Villanyian site at Rębielice Królewskie; its and width/length measurement correspond exactly (Table 1).

Galemys kormosi is known from only six sites in continental Western Europe (Rumke, 1985), including the type locality Beremend 4, Hungary and Beremend 5; Rębielice Królewskie 1 and 2, Poland and Baza, Spain, (all early Villanyian) as well as Tegelen, the Netherlands of Late Villanyian age (Fig. 7). The present report from Sidestrand, East Runton and West Runton extends its geographical range to the Norfolk Weybourne Crags of Pre-Pastonian/Pastonian age. The probable correlation of these sites with continental sites will be discussed 
later in our definitive report on the site. Mayhew and Stuart (1986) regard the vole fauna of Sidestrand, East and West Runton as a Group 1 fauna, correlating in age with Tegelen in the Netherlands. The presence of $G$. kormosi in all three localities certainly supports this view.

Table 1

A comparison of a single right $\mathrm{p}^{4}$ (WRC 614) of Galemys kormosi from West Runton, Norfolk with similar material from two sites in Europe.

\begin{tabular}{|c|c|c|c|}
\hline Locality & $\mathrm{n}$ & mean & range \\
\hline \multicolumn{4}{|c|}{ length (L) } \\
\hline WRC 614 & (West Runton) 1 & $2.31 \mathrm{~mm}$ & - \\
\hline Tegelen & 11 & $2.24 \mathrm{~mm}$ & $2.20-2.29 \mathrm{~mm}$ \\
\hline Rębielice & Królewskie I & $2.44 \mathrm{~mm}$ & $2.34-2.62 \mathrm{~mm}$ \\
\hline \multicolumn{4}{|c|}{ width $(\mathrm{W})$} \\
\hline WRC 614 & (West Runton) 1 & $1.95 \mathrm{~mm}$ & - \\
\hline Tegelen & 11 & $1.88 \mathrm{~mm}$ & $1.77-1.96 \mathrm{~mm}$ \\
\hline Rębielice & Królewskie I & $2.04 \mathrm{~mm}$ & $1.91-2.16 \mathrm{~mm}$ \\
\hline \multicolumn{4}{|c|}{ width/length $(\mathrm{W} / \mathrm{L})$} \\
\hline WRC 614 & (West Runton) 1 & 0.83 & - \\
\hline Tegelen & 11 & 0.84 & $0.79-0.88$ \\
\hline Rębielice & Królewskie I & 0.84 & $0.80-0.91$ \\
\hline
\end{tabular}

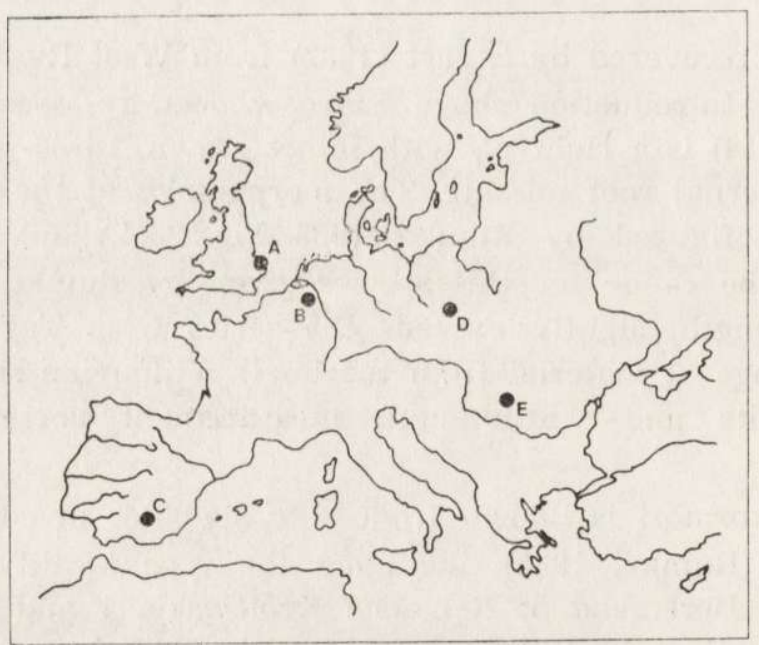

Fig. 7. Lower Pleistocene (Villanyian) distribution of Galemys kormosi. (Continental localities after Rumke, 1985). A: West Runton, Norfolk, England, East Runton, Norfolk, England, Sidestrand, Norfolk, England, B: Tegelen, the Netherlands.

C: Baza, Spain. D: Rębielice Królewskie, Poland. E: Beremend, Hungary. 
It is noteworthy that the incursion of Galemys into the British Pleistocene fauna was comparatively brief, apparently being confined to the Lower Pleistocene. It has not been found in any of the later Middle Pleistocene British faunas. It is also clear that since the Lower Pleistocene, the geographical range of Galemys has contracted southwards since the distribution of the extant species is now confined to the Pyrenees and the rivers and canals of the north-western half of the Iberian Peninsula (Corbet, 1966).

This contraction in the range of Galemys may have resulted from its inability to compete successfully with the water shrews of the genus Neomys. These shrews first appear in the fossil record of Western Europe in the Middle Pleistocene (Hinton, 1911; Kurten, 1968). In England they are known to co-exist with Desmana, in the Cromerian Interglacial, but not with Galemys. Possibly a northern water shrew of the genus Neomys, well adapted to an aquatic life, displaced Galemys from its previous range in western central Europe. It is notable that today the northern water shrew Neomys fodiens, and the pyrenean desman, Galemys pyrenaicus have essentially allopatric distributions although there is some overlap within the river systems of the Pyrenees (Corbet, 1966). In contrast, the southern water shrew, Neomys anomalus, has a general distribution that includes the known range of Galemys pyrenaicus, however, this species is thought to be less confined to aquatic habitats than Neomys fodiens and may therefore prove to be less of an ecological competitor to Galemys than the northern water shrew.

The large Desmana, which is more molluscivorous in diet (Ognev, 1928; Peyre, 1956) and possibly better cold-adapted than Galemys, persisted in Britain until broadly Hoxnian times (Stuart, 1982). Unlike Galemys it retreated eastwards during the Upper Pleistocene to exist today only as a relict population in the Soviet Union (Ognev, 1928). The reason for this is not clear but one can surmise that the long history of the Desmaninae, extending back to the Miocene (Rumke, 1985) is drawing to a close. The Talpinae, on the other hand, continue to be a highly successful group of fossorial mammals, which have produced new semi-aquatic specialists such as the North American Condylura.

Acknowledgements: We are greatly indebted to Dr. Adrian Friday, University Museum of Zoology, Cambridge for the opportunity to study the specimen from West Runton and to John E. Hill, Mammal section, British Museum (Natural History) for the loan of skeletal Desman material. We are also indebted to our colleagaues Dr. A. J. Stuart and Dr. D. F. Mayhew for their helpful advice and to Martin Warren for his great assistance with the geology. Much help in the field has been given by Hon. Mrs. Jonathan Balcon and Michael Ford. 


\section{REFERENCES}

1. Bishop M. J.' 1982: The Mammal Fauna of the early Middle Pleistocene cavern infill site of Westbury-Sub-Mendip, Somerset. Palaeont. Ass. Sp. Papers in Palaeontology, 28: 1-108.

2. Corbet G. B., 1966. The terrestrial mammals of Western Europe. G. T. Foulis \& Co. Ltd., London. $1-264$.

3. Freudenthal M., Meyer T. \& Van der Meulen A. J., 1976: Preliminary report on a f:eld campaign in the continental Pleistocene of Tegelen (the Netherlands). Scripta Geologica, 34: 1-27.

4 Geoffroy E., 1811: Ann, Mus. d'Hist. Nat. XVII: 192-193.

5. Hinton M. A. C.., 1911: The British Fossil Shrews. Geol. Mag. N. S. 8(12): $529-539$.

6. Kormos T., 1930: Desmana thermalis n sp. eine neue praglaziale Bisamspitzmaus aus Ungarn. Ann. Mus. Nat. Hung., 27: 1-19.

7. Kurten B., 1968: Pleistocene Mammals of Europe. Weidenfeld \& Nicolson, London 1 -317.

8. Mayhew D. F., 1985: Preliminary report of research project on small mammal remains from British Lower Pleistocene sediments. Quaternary Newsletter, $47: 1-4$.

9. Mayhew D. F. \& Stuart A. J., 1986: Stratigraphic and taxonomic revision of the fossil vole remains (Rodentia, Microtinae) from the Lower Pleistocene desposits of Eastern England. Phil. Trans. R. Soc. Lond. B, 312: 431-485.

10. Ognev S. I.., 1928: Mammals of Eastern Europe and Northern Asia. Vol 1. Insectivora and Chiroptera. Glavnauka. Moscow. 1-631.

11. Peyre A., 1956: Ecologie et biogeographie du desman (Galemys pyrenaicus G.) dans les Pyrenees francaises. Mammalia, 20: 405-418.

12. Rumke C. G.., 1985: A review of fossil and recent Desmaninae (Talpidae, Insectivora). Utrecht Micropal. Bull. Sp. Pub.,4: 1-241.

13. Schreuder A., 1940: A revision of the fossil water moles (Desmaninae). Extr. Arch. Neerl. Zool., IV: 202-333.

14. Stuart A. J., 1982: Pleistocene vertebrates in the British Isles. Longman, London. $1-212$.

15. West R. G., 1980: The pre-glacial Pleistocene of the Norfolk and Suffolk coasts. Cam. Univ. Press. 1-203.

Received 20 October 1987, Accepted 1 February 1988.

\section{L. HARRISON, P. J. J. BATES i J. D. CLAYDEN}

\section{WYSTĘPOWANIE GALEMYS KORMOSI (SCHREUDER, 1940) (INSECTIVORA: DESMANINAE) W DOLNYM PLEISTOCENIE WIELKIEJ BRYTANII}

\section{Streszczenie}

Po raz pierwszy stwierdzono występowanie Galemys kormosi na Wyspach Brytyjskich. Znalezisko pochodzi z warstw Pre-Pastonian/ Crags z Dolnego Plejstocenu w Sidestrand i East Runton oraz West Runton, Norfolk. Odpowiada to występowaniu tego gatunku w okresie Późnego Villanyian na kontynencie europejskim. 